\title{
A Pharmacognostical and Phytochemical study of Kanchanara Gutika
}

\author{
Research Article
}

\section{Gnana Prasuna $\mathrm{S}^{1 *}$, Manu $\mathrm{R}^{2}$, Pavan Kumar $\mathrm{S}^{3}$, Harinatha Chary $\mathbf{B}^{1}$}

\author{
1. PhD Scholar, 2. Professor, Department of Kayachikitsa, \\ Parul Institute of Ayurveda, Parul University, Vadodara, Gujarat India. \\ 3. Associate Professor, Department of Dravya Guna, \\ S.V.Ayurvedic College, TTD, Tirupati, India.
}

\begin{abstract}
Kanchanara gutika is one of the preparations of the Ayurveda, which is used for the treatment of the Thyroid disorders. It is in use since many years with good clinical outcome. But the pharmacognostic and phytochemical studies of the drug has not been carried out yet. Hence to study them this study is planned. Aim: Authentication of the raw drugs of Kanchanara gutika and phytochemical evaluation of the finished product. Materials and methods: The present study deals with the Pharmacognostical identification of the ingredients of Kanchanara Gutika and its physicochemical analysis. Thin Layer chromatography study (TLC) was also developed.Results: Pharmacognostical results showed Pippali catkin with fruit, Maricha with the epicarp and the oil globules, Sunti with oleoresins and vascular bundles, Haritaki with fibres, Amlaki with epicarp and mesocarp, Vibhithaki with stone cells and Kanchanara with xylem and phloem vessels. Qualitative studies shows that Loss of drying 33\%, PH 4.72\%, Water soluble matter $12 \%$, Alcohol soluble matter 19\%, Total ash 3\%, Acid insoluble ash $2.5 \%$, Dissolution time $4 \%$, Moisture content $8 \%$. The TLC chromatograph showed five bands at Rf 0.21(Yellow), 0.28 (Grey), 0.47 (Brown), 0.56 (Violet), 0.93 (Orange).Conclusion: Pharmacognostical study revealed genuineness of the raw drugs. Physicochemical and TLC studies inferred that the formulation meets the minimum quality standards. The inference from this study may be used as reference standard in the further quality control researches.
\end{abstract}

Key Words: Endocrinal disorders, Hypothyroidism, Galaganda, Kanchanara Gutika, Thin Layer Chromatography study.

\section{Introduction}

The quest for the plant-based medicines is on a high rise these days for various ailments. The modern pharmaceutical products being used for various ailments are having few complications or side effects. Hence to protect the mankind, few herbal based medicines are being tried and tested now a days for the treatment of the disease. In some cases, both are used to have a synergetic effect.

Thyroid disorders are one of the most rapidly evolving endocrinal disorders of the present day. The prevalence of hypothyroidism is more when compared to other thyroid disorders. The clinical features supported by the laboratory investigations help us to come at a correct diagnosis. The clinical features include local features as swelling in the neck region, hoarseness of the voice and systemic features as weight gain, tremors and the like. Hormonal replacement with Thyroxin is providing satisfactory results to some extent but the quality of the life of the individual is not improving to the level of the stage of expectation. The

\section{* Corresponding Author:}

\section{Gnana Prasuna $S$}

$\mathrm{PhD}$ scholar, Department of Kayachikitsa,

Parul Institute of Ayurveda,

Parul University, Vadodara, Gujarat India.

Email Id:_drsgprasuna@gmail.com side-effects of Thyroxin are becoming the root cause for the research in other systems of medicine to combat hypothyroidism. The clinical feature, swelling in the neck region in Ayurveda is considered as Galaganda.

Ayurvedic system of medicine advocates the uses of natural and herbal medicines for all the ailments. Kanchanara gutika, is one of the preparations mentioned in the texts of Ayurveda, used for the diseases like galaganda, gandamala (which are similar to the clinical conditions of Thyroid disorders). It is a combination of Triphala, Trikatu, Kanchanara etc, which are also proved to be highly effective in controlling the thyroid levels in the body.

Even though Kanchanara gutika is used since along time in the management of the thyroid disorders, standardization of the formulation has not been done with the pharmacognostical and phytochemical parameters. The individual drugs mentioned are standardized and are included in the Ayurvedic Pharmacopoeia of India.

Hence an attempt to know the pharmacognostical and phytochemical characters of the Kanchanara gutika this pilot study is taken and the results are presented.

\section{Aims and Objectives}

- To study the macroscopic and microscopic characteristics of the individual drugs mentioned in Kanchanara gutika. 
- To Study the phytochemical characters of the Kanchanara gutika preparation.

- Compare the results with the standard literature available.

\section{Materials and Methods:}

All the ingredients of Kanchanara Gutika were procured from the local markets of Tirupati, Andhra Pradesh. The raw drugs were authenticated by the the Dept of Dravya Guna, S.V. Ayurveda College, TTD, Tirupati. The ingredients and the part used are given in (Table no.1)

Table 1. Ingredients of Kanchanara Gutika

\begin{tabular}{|c|c|c|c|c|c|}
\hline \multirow{2}{*}{$\begin{array}{c}\text { Sl. } \\
\text { No. } \\
1\end{array}$} & \multicolumn{3}{|c|}{ Drug Name } & \multirow{2}{*}{$\begin{array}{l}\text { Part } \\
\text { used } \\
\text { Fruit } \\
\text { pulp }\end{array}$} & \multirow{2}{*}{$\begin{array}{l}\text { Ratio } \\
3 \text { part } \\
\text { (1 part } \\
\text { each) }\end{array}$} \\
\hline & Triphala & Haritaki & $\begin{array}{l}\text { Terminalia } \\
\text { chebula } \\
\text { Retz. }\end{array}$ & & \\
\hline & & Vibhitaki & $\begin{array}{l}\text { Terminalia } \\
\text { bellirica } \\
\text { (Gaertn.) } \\
\text { Roxb. }\end{array}$ & $\begin{array}{l}\text { Fruit } \\
\text { pulp }\end{array}$ & \\
\hline & & Amalaki & $\begin{array}{l}\text { Phyllanthus } \\
\text { emblica L. }\end{array}$ & $\begin{array}{l}\text { Fruit } \\
\text { pulp }\end{array}$ & \\
\hline \multirow[t]{3}{*}{2} & Trikatu & Pippali & $\begin{array}{l}\text { Piper } \\
\text { longum } \mathrm{L} .\end{array}$ & $\begin{array}{l}\text { Fruit } \\
\text { catkin }\end{array}$ & $\begin{array}{l}6 \text { parts } \\
(2 \text { parts } \\
\text { each })\end{array}$ \\
\hline & & Shunti & $\begin{array}{l}\text { Zingiber } \\
\text { officinale } \\
\text { Roscoe. }\end{array}$ & $\begin{array}{l}\text { Rhizo } \\
\text { me }\end{array}$ & \\
\hline & & Marica & $\begin{array}{l}\text { Piper } \\
\text { nigrum L. }\end{array}$ & Fruits & \\
\hline 3 & \multicolumn{2}{|c|}{ Kanchanara twak } & $\begin{array}{l}\text { Bauhinia } \\
\text { variegata } \\
\text { (L.) Benth }\end{array}$ & Bark & 12 parts \\
\hline 4 & \multicolumn{2}{|l|}{ Guggulu } & $\begin{array}{l}\text { Commiphora } \\
\text { wightii } \\
\text { (Arn.) } \\
\text { Bhandari }\end{array}$ & Gum & 21 parts \\
\hline 5 & \multicolumn{2}{|l|}{ Honey } & & & 30 parts \\
\hline
\end{tabular}

\section{Method of Preparation of Kanchanara Gutika}

Ingredients enlisted in Table 1 were collected from the local market in Tirupati and are shade dried. They are cleaned to remove any foreign material. Then the ingredients are made into fine powder individually. The individual ingredients are weighed according to the ratio mentioned in table 1 and are mixed in a mass mixing machine. After a homogeneous mixture was obtained purified Guggulu (purified by Triphala Kwatha was added). Finally, honey was added. To make the preparation more palatable, it is made into soft gel capsules for the clinical use. The weight of each capsule is $1000 \mathrm{mg}+/-1 \%$. It was oval in shape, dark in colour with pleasant odour and soft to touch. It can be stored and kept in well closed containers.

\section{Pharmacognostical study}

The pharmacognostical study of the individual ingredients used in the study and the authentication of the ingredients was done at Department of Dravyaguna, SV Ayurvedic College, as per the standard format of the Macroscopic and microscopic identification process mentioned in the API format. The characters were

correlated with the standard findings mentioned in API volumes regarding the individual drugs.

\section{Phytochemical study}

This Gutika was analyzed using various standard physicochemical parameters as per API at the Varun Herbals Research and Testing Lab, Hyderabad, Telangana.

\section{Observations and Results}

Organoleptic parameters: Organoleptic parameters (2) like, Colour, odour and touch were scientifically studied and results were depicted in the table. (Table 2)

Physico-chemical analysis: Physicochemical parameters of Kanchanara gutika like Uniformity of the weight, Loss on drying(3), $\mathrm{Ph}(4)$, Ash Value, Water soluble extract(5), Methanol soluble extract(6), Acid insoluble ash and TLC were evaluated. The results are depicted in Table no.3.

Table 2: Organoleptic properties of Kanchanara Gutika

\begin{tabular}{|l|l|}
\hline Odour & Pleasant \\
\hline Colour & Thick Brown \\
\hline Touch & Soft \\
\hline
\end{tabular}

Table 3: Physico-chemical parameters of Kanchanara Gutika

\begin{tabular}{|l|l|l|l|l|}
\hline $\begin{array}{l}\text { S.No } \\
\cdot\end{array}$ & Test Parameters & $\begin{array}{l}\text { Method/ } \\
\text { SOP No. }\end{array}$ & Results & $\begin{array}{l}\text { Unit of } \\
\text { measure } \\
\text { ment }\end{array}$ \\
\hline 1 & Loss of drying & API & 3.3 & $\%$ \\
\hline 2 & $\begin{array}{l}\text { Water soluble } \\
\text { matter }\end{array}$ & API & 12 & $\%$ \\
\hline 3 & $\begin{array}{l}\text { Alcohol soluble } \\
\text { matter }\end{array}$ & API & 19 & $\%$ \\
\hline 4 & Total ash & API & 3 & $\%$ \\
\hline 5 & $\begin{array}{l}\text { Acid insoluble } \\
\text { ash }\end{array}$ & API & 2.5 & $\%$ \\
\hline 6 & PH & API & 4.72 & $\%$ \\
\hline 7 & Dissolution time & API & 4 & min \\
\hline 8 & Moisture content & API & 8 & $\%$ \\
\hline
\end{tabular}

Microscopic characters of the ingredients of Kanchanara Gutika

Figure 1: Transverse section of the Pippali fruit

Figure 1a: Catkin with fruit

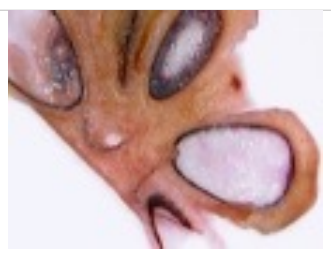

Figure 1c:

Fruit section enlarged with different layers 
Figure 2: Transverse section of the Maricha fruit

\begin{tabular}{|l|l|l|} 
T.S of the fruit & $\begin{array}{l}\text { Enlarged fruit } \\
\text { section with oil } \\
\text { globules }\end{array}$ & $\begin{array}{l}\text { Enlarged fruit } \\
\text { section view of } \\
\text { the epicarp and } \\
\text { the oil globules }\end{array}$ \\
\hline
\end{tabular}

Figure 3: Transverse section of the Shunti fruit

T.S of Sunti

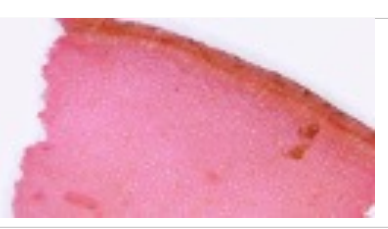

Figure 4: Transverse section of the Haritaki fruit pulp T.S of Hareetaki fruit

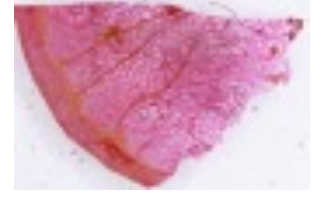

Figure 5: Transverse section of the Amalaki fruit pulp T.S of fruit

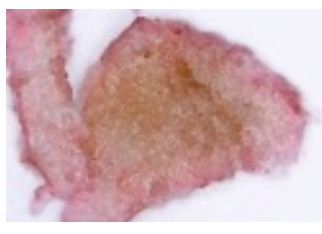

Figure 6: Transverse section of the Vibhitaki fruit pulp T.S of Vibhitaki fruit

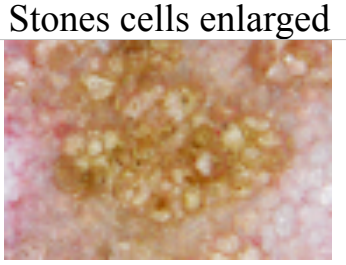

Figure 7: Transverse section of the Kanchanar stem Enalrged section with T.S. of stem annual ring with xylem vessels \& phloem

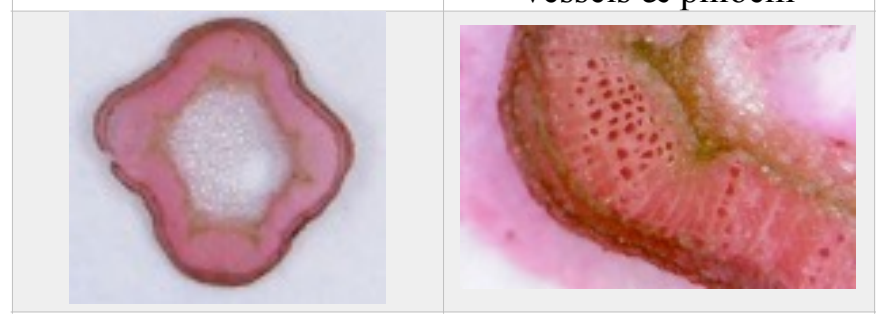

\section{Thin layer chromatography study (TLC):}

TLC study was carried out by VHIP method using Toulene and Ethyl acetate (9:1) during the mobile phase and Silica gel during the stationary phase. Vanillin and $\mathrm{H}_{2} \mathrm{SO}_{4}$ reagent was the spraying agent used for the TLC Study. The chromatograph showed five bands at Rf 0.21(Yellow), 0.28 (Grey), 0.47 (Brown), 0.56 (Violet), 0.93 (Orange). Rf values of the bands obtained were at a comparable level which indicates the presence of some definite constituents in the sample. The results are depicted in Table no. 4 .

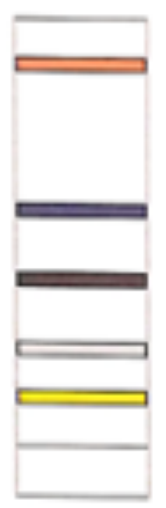

Figure 8: TLC Study

Rf values:

Five bands at Rf

0.21 (Yellow),

0.28 (Grey),

0.47 (Brown),

0.56 (Violet),

0.93 (Orange).

Table 4: Results of TLC of Kanchanara Gutika

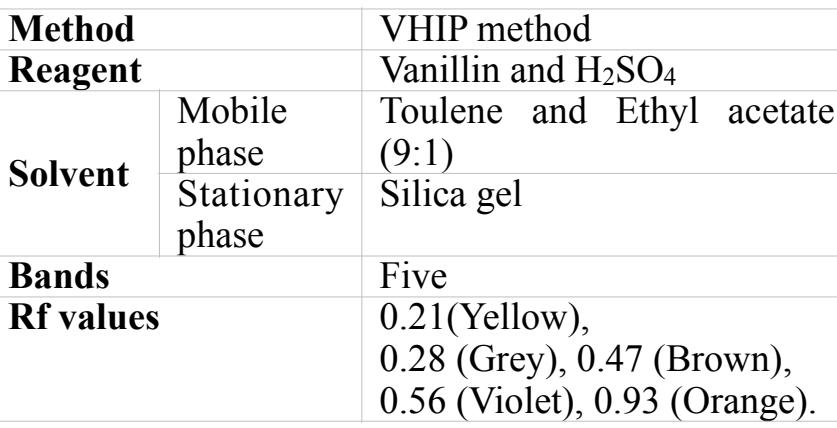

\section{Discussion}

Pharmacognostical evaluation of Kanchanara gutika showed the specific characters of all the ingredients which were used in the preparation.

\section{Pippali (Piper longum Linn.)}

The transverse section showed catkin with fruit. The fruit T.S showed different layers as the outer epidermis with a thick cuticle, the middle thin layered mesocarp and an inner endocarp filled with starch grains $(8)$. The phyto chemical analysis of Pippali powder showed the presence of phenol compounds (tannins), saponins, proteins, amino acids, flavonoids, steroids and triterpenoids.

\section{Maricha (Piper Nigram Linn)}

The transverse section of the fruit showed a thick pericarp. The enlarged section of the fruit showed the three layers of pericarp which includes the epicarp, mesocarp and endocarp. The epicarp showed epidermis and the mesocarp showed oil cells present in the outer region8. The phyto-chemical analysis of Maricha powder 
showed the presence of phenol compounds (tannins) saponins, proteins, aminoacids, steroids and triterpenoids.

\section{Shunti (Zingiber officinale Roxb.)}

Transverse section of the rhizome showed cortex with parenchyma and idioblasts with yellow brown oleoresins. The endodermis showed vascular bundles(9). Phytochemical analysis of Sunti exhibited the presence of steroids, triterpenoids, phenolic compounds, tannins and acids.

\section{Haritaki (Terminalia Chebula Retz.)}

The transverse section of the fruit showed epicarp, mesocarp and endocarp. The enlarged section showed mesocarp with vascular bundles and fibers with peg like out growths(10). The phyto-chemical analysis of Haritaki powder showed the presence of phenol compounds, saponins, proteins, amino acids, flavonoids, steroids, triterpenoids and acids.

\section{Amalaki (Emblica officianalis Gaert.)}

The Transverse section of the fruit showed epicarp with a single layered epidermis and mesocarp with parenchymatous cells (11). The phytochemical analysis showed the presence of carbohydrates, glycosides, phenol compounds, saponins, proteins, amino acids, flavonoids, steroids and triterpenoids.

\section{Vibhitaki (Terminalia bellerica Roxb.)}

The phytochemical analysis of Vibhitaki powder showed the presence of phenol compounds (tannins), proteins and amino acids, flavonoids and presence of acids. Transverse section of the fruit showed an outer epicarp and inner mesocarp. Epicarp contained stone cells in the periphery and the mesocarp showed stone cells in groups (12).

\section{Kanchanara (Bauhinia variegata Linn.)}

Transverse section of mature stem bark showed cortex with an outer and an inner cork and a secondary cortex. The enlarged section showed annual rings with xylem vessels and phloem (13). The phytochemical analysis of Kanchanara powder showed the presence of carbohydrates, cardiac glycosides, tannins, steroids and triterpenoids

\section{Guggulu (Commiphora mukul Hook Ex Stocks.)}

Phyto-chemical analysis of guggulu resin showed the presence of flavonoids, steroids, triterpenoids, acids and carbohydrates.

\section{Madhu (Honey)}

Phytochemical analysis of madhu has showed the presence of carbohydrates, glycosides, phenolic compounds (tannins), saponins, proteins, amino acids and flavonoids.

\section{Phytochemical analysis of Kanchanara Gutika}

Phyto-chemical analysis of the finished drug Kanchanara gutika showed the presence of the phenol compounds tannins, saponins, proteins, amino acids, flavonoids, steroids, triterpenoids, acids, anthraquinone glycosides and carbohydrates.

\section{Physicochemical analysis of Kanchanara Gutika}

The physico-chemical analysis showed Loss of drying 33\%, PH $4.72 \%$, Water soluble matter $12 \%$, Alcohol soluble matter $19 \%$, Total ash $3 \%$, Acid insoluble ash $2.5 \%$, Dissolution time $4 \%$, Moisture content $8 \%$. Kanchanara gutika was dark brown in colour with a pleasant odour and soft to touch. The TLC chromatograph showed five bands at Rf 0.21(Yellow), 0.28 (Grey), 0.47 (Brown), 0.56 (Violet), 0.93 (Orange). $\mathrm{Rf}$ values of the bands obtained were at a comparable level which indicates the presence of some definite constituents in the sample.

\section{Conclusion}

Thus, from the above study it can be concluded that the kanchanara gutika prepared with the genuine ingredients will be dark brown in colour, pleasant in odour and soft to touch. It contains tannins, saponins, proteins, flavonoids, steroids etc which are also a part of the independent ingredients used. On TLC it produces five bands at rf. values $0.21,0.28,0.47,0.56$ and 0.93 . Thus, this study and give a guideline for further research and stadardization of Kanchanara gutika.

\section{Conflict of interest: None Sources of funding: None}

\section{References}

1. Bhaishajya Ratnavali Siddiprada Hindi vakya sahita by Siddhinandan Misra, Galaganda gandamala apachi grandhi arbuda adhikara, 60-62 sloka, 2001 published Chaukhamba Surbharati Prakashan, Varanasi, 2009 p.806,

2. Kokate CK, Purohit AP, Gokhale SB. Pharmacognosy. 42nd ed. Pune: Nirali Prakashan; 2008; p.102.

3. Anonymous 2. The Ayurvedic Pharmacopoeia of India, 1st Edition,Ministry of Health and Family Welfare, Govt. of India, Part I, I1999, Appendix - 2, 214 (2.2.9).

4. Anonymous 3. The Ayurvedic Pharmacopoeia of India, $1^{\text {st }}$ ed., Ministry of Health and Family Welfare, Govt. of India, Part I, I1999, Appendix - 3, 230 (3.3).

5. Anonymous 4. The Ayurvedic Pharmacopoeia of

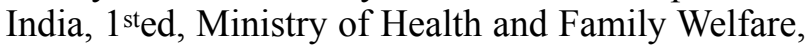
Govt. of India, Part I, I1999,Appendix -214(2.2.7).

6. Anonymous 5.The Ayurvedic Pharmacopoeia of India, 1st Edition,Ministry of Health and Family Welfare, Govt. of India, Part I, 1999, Appendix - 2, 214 (2.2.6).

7. Anonymous. The Ayurvedic Pharmacopoeia of India Part 1, Vol 4, $1^{\text {st }}$ ed., Ministry of Health and Family Welfare, Govt. of India, Page No. 91.

8. Anonymous. The Ayurvedic Pharmacopoeia of India Part 1, Vol 3, 1st ed., Ministry of Health and Family Welfare, Govt. of India, Page No 173. 
9. Anonymous. The Ayurvedic Pharmacopoeia of India Part 1, Vol 2, 1st ed., Ministry of Health and Family Welfare, Govt. of India, Page No 12.

10. Anonymous. The Ayurvedic Pharmacopoeia of India Part 1, Vol 1, 1st ed., Ministry of Health and Family Welfare, Govt. of India, Page No 47.

11. Ayurvedic Pharmacopoeia of India, Govt. of India, Ministry of health and family welfare, dept. of
AYUSH, New Delhi, part 1, vol. 1, first edition, p. 5-6.

12. Anonymous. The Ayurvedic Pharmacopoeia of India Part 1, Vol 1, 1st ed., Ministry of Health and Family Welfare, Govt. of India, Page No 26.

13. Anonymous. The Ayurvedic Pharmacopoeia of India Part 1, Vol 1, 1st ed., Ministry of Health and Family Welfare, Govt. of India, Page No 95. 